\title{
1 Do Higher Fuel Prices Help Reduce Road Traffic Accidents?
}

$4 \quad$ Nadia K. Naqvi

$5 \quad$ Research Student

6 Transport Studies Group

7 School of Architecture, Building and Civil Engineering, Loughborough University,

8 Loughborough, Leicestershire, LE11 3TU, UK

$9 \quad$ Tel: +44 (0)7828120948, Email: n.k.naqvi@lboro.ac.uk

10

11 Professor Mohammed A. Quddus

12 Professor of Intelligent Transport Systems

13 Transport Studies Group

14 School of Architecture, Building and Civil Engineering

15 Loughborough University,

16 Loughborough, Leicestershire, LE11 3TU, UK

17 Tel: +44 (0)1509 228545, Email: m.a.quddus@1boro.ac.uk

19 Professor Marcus P. Enoch (corresponding author)

20 Professor in Transport Strategy

21 Transport Studies Group

22 School of Architecture, Building and Civil Engineering, Loughborough University,

23 Loughborough, Leicestershire, LE11 3TU, UK

24 Tel: + +44 (0)1509 223408, Email: m.p.enoch@lboro.ac.uk 


\section{ABSTRACT}

2 Road traffic accidents have decreased in most developed nations over the last decade. This

3 has been attributed to improvements in vehicle and road design, medical technology and care,

4 and driver education and training. Recent evidence however indicates that fuel price changes

5 also have a significant impact on road traffic accidents through other mediating factors such

6 as reductions in driver exposure through less car travel and more fuel-efficient driving e.g.

7 speed reduction on high-speed roads. So far though, no study has examined the effects of

8 changing fuel prices on road traffic accidents in a country such as Great Britain where fuel

9 prices are kept artificially high for public policy reasons. Consequently, this study was

10 designed to quantify the effects of fuel price on road traffic accident frequency through

11 changes and adjustments in travel behaviour. For this purpose, weekly fuel prices (between

12 2005-2015) have been used to study the effects on road traffic accidents using the Prais-

13 Winsten model of first order autoregressive (AR1) and the Box and Jenkins seasonal

14 autoregressive integrated moving average models (SARIMA). The study found that with 15 every $1 \%$ increase in fuel price there is a $0.4 \%$ reduction in the number of fatal road traffic

16 accidents. In light of this, one concern raised was that recent UK government plans to phase 17 out petrol and diesel vehicles by 2040 may also risk a rise in fatal road traffic accidents, and 18 hence this will need to be addressed. 


\section{$1 \quad 1$ INTRODUCTION}

2 More than 1.25 million people die on the world's roads and millions more suffer serious

3 injuries each year as a result of road traffic accidents, which cost most nations around $3 \%$ of

4 their GDP (Toroyan et al., 2015), with the average societal benefit of preventing a fatal

5 accident on British roads for example, being estimated to be just over $£ 2$ million (Blincoe et

6 al., 2015; Department for Transport, 2016). Preventing road traffic accidents has therefore

7 been a key transport policy for many countries. In the context of Great Britain, even though

8 the roads are considered to be amongst the safest in the world, there were still 1,720 reported

9 road deaths and 174,510 casualties of all severities in 2017 (Department for Transport, 2018).

10 That said, the number of fatalities was still some $42 \%$ less when compared with the figure in

112006 (Department for Transport, 2015a), and this begs the question, why?

12 One thought is that periods of economic recession (such as those in 1990-1992 and in

13 2006-2010) coupled with high fuel prices over the same period have played an important part

14 in reducing road accident fatalities (Department for Transport, 2015b). Thus Figure 1 shows

15 how the number of road traffic accidents has fallen in Great Britain between 2005 and 2015

16 along with corresponding petrol and diesel price fluctuations.

17 This understanding is especially important in the British context where fuel prices are 18 relatively high compared to other countries (Noel et al., 2016). These higher fuel prices are

19 largely due to high rates of fuel duty which for many years have been targeted at two main

20 policy objectives. First, higher fuel prices are aimed at reducing road externalities (carbon

21 dioxide, air pollution, congestion and accidents) and second, at generating tax revenues (some

$22 £ 27.9$ billion in $2017 / 2018$ according to RAC Foundation, 2017) of which some has been

23 spent on road safety schemes (Parry, 2001; Santos et al., 2010). Consequently, if higher fuel

24 prices do lead to fewer accidents, then this relationship needs to be better understood. 


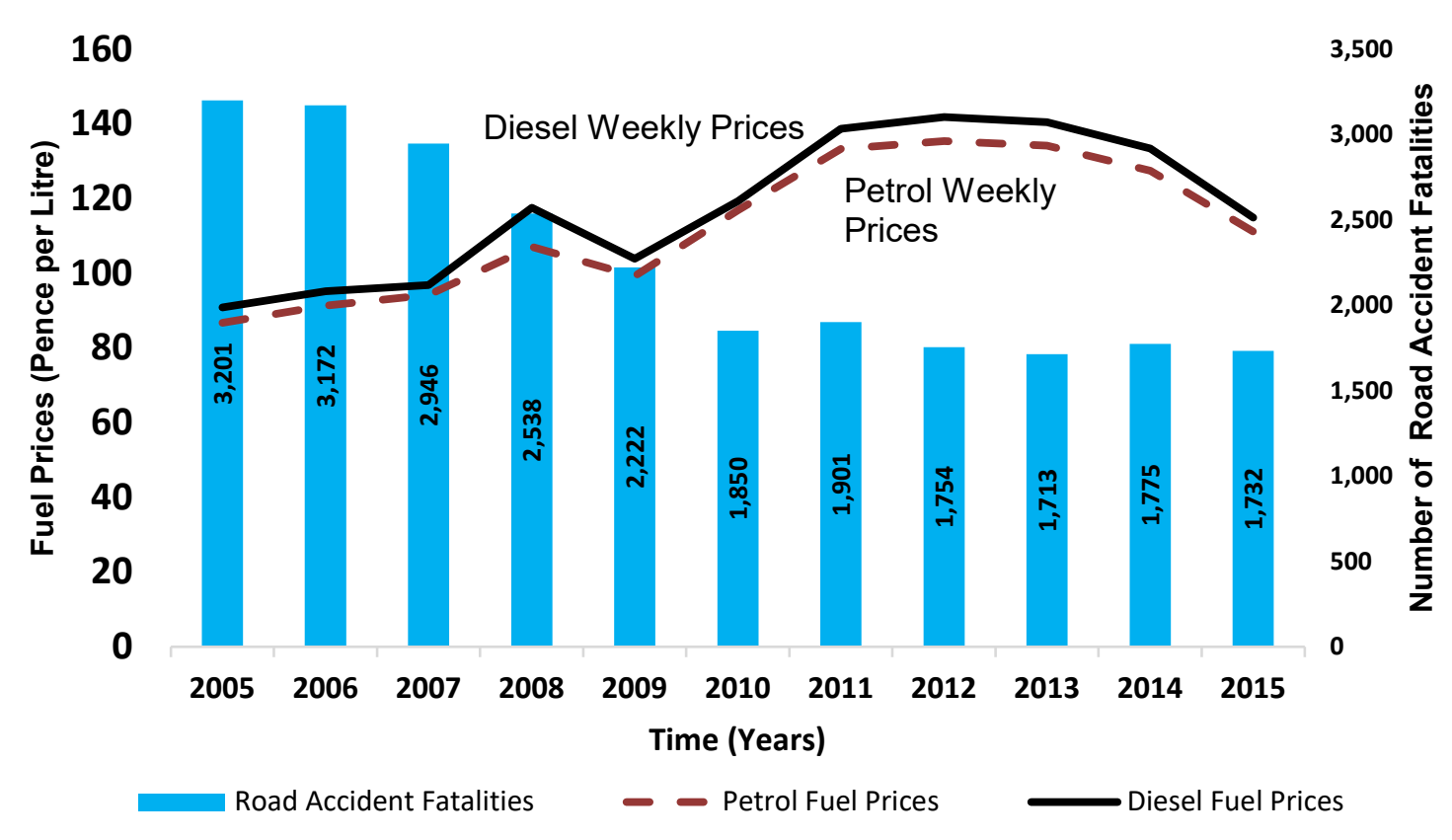

FIGURE 1 Road Accident Fatalities and Fuel Price Fluctuation in Great Britain (2005-2015)

4 This issue is especially pertinent at the moment, because political sensitivities about poor air

5 quality and climate change are now pushing Government in the direction of scrapping

6 vehicles powered by internal combustion engines, with one recent announcement proposing

7 a complete ban on petrol and diesel vehicles in the UK by 2040 (BBC, 2017), and this coupled

8 with rapid recent developments in alternative power source technologies mean that sales of

9 diesel vehicles in particular are already declining. Thus car registration data show that diesel

10 vehicle sales fell from 103,564 to 74,361 (i.e. by 28.2\%) between June 2017 and June 2018,

11 with the demand replaced with 15,866 (12.3\%) more petrol vehicles and $4828(45 \%)$ more

12 alternative fuel vehicles (AFV) (SMMT, 2018). Bluntly, whilst such a shift from the internal

13 combustion engine could well improve health outcomes and reduce energy use and carbon

14 emissions, it may also inadvertently lead to an increased number of accidents, firstly by 
1 encouraging more and longer vehicle trips, and secondly by reducing fuel tax revenues and

2 thus cutting spending on road safety improvement schemes.

Hence this question of how fuel price changes affect the number of road accidents in

4 Great Britain forms the focus of this paper. The paper is structured as follows: section 2

5 presents previous research, section 3 details the data, and section 4 describes the methodology.

6 Section 5 outlines the results, and section 6 provides a discussion and the conclusions.

7

\section{PREVIOUS RESEARCH}

Overall, only a small number of studies have looked specifically at the relationship between fuel price changes and the level of road safety, specifically between fuel prices and the number of road accident fatalities (e.g. Burke and Nishitateno, 2015; Grabowski and Morrisey, 2004), else between fuel prices and the number of road traffic accidents (Chi et al., 2012; RodríguezLópez et al., 2016). So far, the overarching finding is that fuel prices are negatively related to road traffic accidents, i.e. that the number of road traffic accidents or fatalities falls as fuel becomes more expensive. For instance, a worldwide study found that an increase of $1 \%$ in fuel prices will cause a corresponding reduction in road accident fatalities of between $3 \%$ and 6\% (Burke and Nishitateno, 2015). This variation in fatalities across different countries depends upon country specific characteristics e.g. medical technology and care, vehicle design, fuel price policy and regulations (fuel subsidies and fuel taxes).

Meanwhile an American study found that with every 1\% increase in gasoline prices there is an immediate $0.25 \%$ reduction in the total accident rate (Chi et al., 2010), with the most impact being recorded on young people of age group (16-19) years old as compared to any other age group due to financial dependency. Next, a longitudinal study of data between 2004 and 2012 found that whilst the fuel price immediately affected the number of accidents for young people, it had no effect for people aged 25-34 and was only significant after a 9-10 
1 month lag for people aged 75 years old and above (Chi et al., 2015). Chi et al. (2013) studied

2 the fuel price effects on road traffic accidents per million VMT in Minnesota (USA), and

3 found a $10 \%$ increase in petrol price reduced total crashes by $4.1 \%$ in rural areas but by only

$42.8 \%$ in urban areas. Similarly, it reported that a $10 \%$ increase in petrol prices led to a decrease

5 in the number of injury-only accidents by $2 \%$ in rural areas and $1.1 \%$ in urban areas, and in

6 property damage only accidents of $5.2 \%$ in rural areas and $3.6 \%$ in urban areas. There was no

$7 \quad$ significant difference between rural and urban fatal crash numbers.

In taking a broader view, there is a significant body of literature relating to the various

9 ways in which drivers react to changes in fuel prices (see Figure 2), particularly from elasticity

10 studies on how they affect travel demand (e.g. Graham and Glaister, 2004; Musso et al., 2013)

11 and fuel consumption (Goodwin et al., 2004), but also in other indirect ways (Burke and

12 Nishitateno, 2015; Grabowski and Morrisey, 2004). Also important, given the assumption

13 that speed and severity of accident are correlated, is a study of the fuel price and speed

14 relationship which found that with every 1 US Dollar increase in fuel price there will be

15 corresponding reduction of $0.27 \mathrm{mph}$ in speed (Wolff, 2014). However, Burger and Kaffine

16 (2015) reported the opposite by noting that a rise in fuel price of 1 US Dollar on freeways in

17 peak periods actually increased average freeway speed by $3.3 \mathrm{mph}$ during rush hours by

18 persuading some people not to drive, thus freeing up road space and reducing congestion.

19 Moreover, they speculated there was a disconnect between fuel buying decisions and choices

20 about driver behaviour, and that drivers were generally unaware of the relationship between

21 driver behaviour and fuel efficiency.

22 Crucially, in understanding what is actually an indirect relationship between fuel price

23 changes and the number of accidents, it is necessary to consider several forms of variables

24 (Elvik, 2003). In this 'causal chain' arrangement, these are the dependent variable, the

25 independent variable, and a third type, which can then be denoted as being either (1) 
1 confounding (sometimes called confounder) variables, (2) mediator (sometimes called

2 intermediate) variables, or (3) effect modifier (sometimes called moderator) variables

3 (Kamangar, 2012). Of these, confounding variables can be defined as being as "a predictor

4 of the outcome, but is also associated with exposure" (Bauman et al., 2002). Examples in this

5 case could include such elements as GDP and weather conditions. For instance, whilst GDP

6 might increase accident numbers by increasing the level of vehicle miles travelled (and hence

7 exposure, (Jokscfi, 1984)), it may also lead to higher investment in road safety and hence

8 reduce the number of accidents (Bishai et al., 2006). Meanwhile the economic growth of a

9 country as measured by GDP will also influence fuel price levels, though fuel prices do not

10 affect GDP directly at least (though crude oil prices may do), and thus GDP is a potential

11 confounding factor candidate. Based on these arguments, a causal diagram is developed to

12 demonstrate how fuel price changes may affect road traffic accidents (Figure 2).

13

16 As for the effects of weather, whilst driving is generally less dangerous during daylight hours 17

\section{FIGURE 2 Causal Diagram of Fuel Price and Road Traffic Accidents}

$$
\text { and in dry conditions, people also tend to drive more thus increasing their exposure }
$$

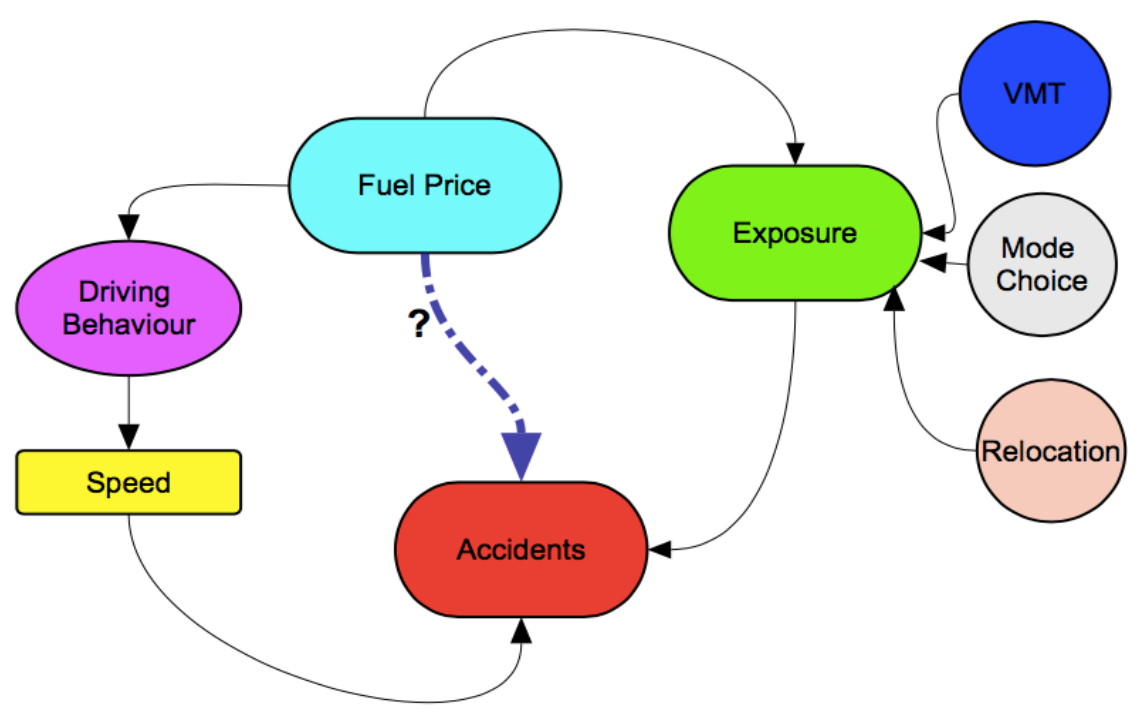


1 (Department of Transport, 2014). Also, weather can influence fuel prices but remains

2 unaffected by fuel price changes and accidents, and hence was identified as a second

3 confounder for this study.

Mediating or intermediate factors are represented by variables which lie in the path of

5 a causal chain of exposure and outcome, unlike a confounder variable (Kamangar, 2012), and

6 for the purpose of this study may include variables such as vehicle miles travelled. Lastly,

7 moderating or effect modifier variables affect the strength of a relationship without being a

8 part of that relationship. An example here would be population, as a change in population

9 would not fit in the casual chain between fuel price and accident relationship, though it would

10 impact on the level of traffic exposure and thus on the number of accidents (Department for

11 Transport, 2016b).

12

13 TABLE 1 Conceptual Framework of Fuel Price Changes and Traffic Accidents

\begin{tabular}{|c|c|c|c|c|}
\hline \multicolumn{2}{|l|}{ Fuel Price Response } & \multirow{2}{*}{\begin{tabular}{|l|} 
Source \\
(Blomquist, \\
$1984)$ \\
(Wolff, 2014)
\end{tabular}} & \multirow{2}{*}{$\begin{array}{l}\text { Potential } \\
\text { Implications For } \\
\text { Accidents } \\
\begin{array}{l}\text { Reduce likelihood } \\
\text { of accident }\end{array}\end{array}$} & \multirow{2}{*}{$\begin{array}{l}\text { Source } \\
\text { (Elvik, 2013) }\end{array}$} \\
\hline $\begin{array}{l}\text { Changes in traffic } \\
\text { dynamics; } \\
\text { Changes in driving } \\
\text { behaviour } \\
\text { (immediate } \\
\text { responses) }\end{array}$ & $\begin{array}{l}\text { Fuel efficient driving(Drive } \\
\text { slower and smoother) } \\
\text { Reducing Speed }\end{array}$ & & & \\
\hline \multirow{4}{*}{$\begin{array}{lr}\text { Changes in } & \text { driving } \\
\text { behaviour } & \text { (short- } \\
\text { medium } & \text { term } \\
\text { responses) } & \end{array}$} & $\begin{array}{l}\text { Trip chain, make multi-purpose } \\
\text { trips }\end{array}$ & \multirow[t]{3}{*}{$\begin{array}{lll}(\mathrm{Chi} & \text { et al., } \\
2013) & & \end{array}$} & \multirow[t]{4}{*}{ Reduce exposure } & \multirow[t]{4}{*}{$\begin{array}{l}\text { (Fridstrøm et } \\
\text { al., 1995) }\end{array}$} \\
\hline & Make shorter trips/less Trips & & & \\
\hline & Share vehicle/car pool & & & \\
\hline & Change mode & 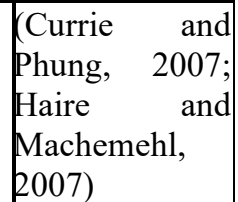 & & \\
\hline \multirow{2}{*}{$\begin{array}{l}\text { Life Style changes } \\
\text { (medium-long term } \\
\text { responses) }\end{array}$} & $\begin{array}{l}\text { Sell vehicle/ replace with new } \\
\text { vehicle }\end{array}$ & $\begin{array}{l}\text { (Busse et al., } \\
\text { 2009) }\end{array}$ & $\begin{array}{l}\text { Increase in severe } \\
\text { accidents }\end{array}$ & $\begin{array}{l}\text { (Ahmad and } \\
\text { Greene, 2005) }\end{array}$ \\
\hline & $\begin{array}{l}\text { Move houses to be closer to } \\
\text { work }\end{array}$ & $\begin{array}{l}\text { (Chi et al., } \\
2017)\end{array}$ & Reduce exposure & $\begin{array}{l}\text { (Fridstrøm et } \\
\text { al., 1995) }\end{array}$ \\
\hline
\end{tabular}


2 Table 1 presents the results of a series of previous studies illustrating how drivers change their

3 driving behaviour, trip making behaviour or their lifestyles in response to fuel price changes;

4 and then reporting how these responses affect the number of accidents.

In conclusion, the current literature is primarily focused on the United States, with

6 only one or two exceptions, such as the world-wide study (Burke and Nishitateno, 2015). To

7 the best of our knowledge, no analysis has been carried out in Great Britain, an environment

8 where the price of fuel is kept artificially high for reasons of policy.

9

103 DATA

11 From the review of the literature, the causal diagram (Figure 2) and the conceptual framework

12 (Table 1), a number of factors were identified, and a dataset was formulated. The dataset of

1315 variables was constructed from a range of secondary data sources, with observations taken

14 from January 2005 to December 2015 for GB (England, Wales and Scotland). The variable

15 characteristics are displayed in Table 2, with more detailed comments provided below where 16 necessary.

Accident and Traffic Data: The dependent variable is the number of accidents per week which was obtained from the so-called STATS19 database (Department for Transport, 2015.) This contains detailed records of each accident e.g. location, number of vehicles involved, time (year, month, day, hour), the severity of accidents and number of casualties. The data is based on police records and is not matched with hospital data. It also does not include property damage accidents nor some minor injury accidents that have not been reported to the police. The raw daily data for total, fatal, serious and slight accidents was converted to weekly counts to use in the statistical analysis. Only one accident is recorded even if there are multiple victims or vehicles involved. Data for vehicle miles travelled for 
1 cars, light goods vehicles, and heavy goods vehicles were only available quarterly from the

2 department for transport (DfT) converted to weekly data using annual average daily traffic

3 (AADT) data, whilst those for road lengths was only available annually (Department for

4 Transport, 2016c, 2017).

Socio-economic Data: Monthly data for unemployment rate data, quarterly gross domestic product GDP per capita and monthly population data for those aged 16 or over was collected for Great Britain from the Office of National Statistics website (Office of National Statistics, 2018, 2017a, 2017b).

Meanwhile, weekly fuel price data for unleaded petrol (ULSP) and unleaded diesel (ULSD) was obtained from the Department for Business, Energy and industrial Strategy

11 (Department for Business Energy and Industrial, 2018). This data is updated every Monday

12 from six participating companies covering $65 \%$ of the UK market and is used as a proxy for

13 the average pump price pence per litre across the country.

14 TABLE 2 Variable Description of Data Collected for Great Britain*

\begin{tabular}{|c|c|c|c|c|c|}
\hline Data Type & Variable & Description & $\begin{array}{l}\text { Available } \\
\text { Frequency }\end{array}$ & Type & Source \\
\hline \multirow[t]{3}{*}{$\begin{array}{l}\text { Road \& } \\
\text { Traffic }\end{array}$} & Accidents & Accidents per week & Hourly & Dependent & $\begin{array}{l}\text { (Department for } \\
\text { Transport, 2015) }\end{array}$ \\
\hline & $\begin{array}{l}\text { Vehicle miles } \\
\text { travelled (VMT) }\end{array}$ & $\begin{array}{l}\text { Separate VMT } \\
\text { variables for Total, } \\
\text { Cars, HGV and } \\
\text { LGV }\end{array}$ & Quarterly & Mediator & $\begin{array}{l}\text { (Department for } \\
\text { Transport (2015), } \\
2017)\end{array}$ \\
\hline & Road length & $\begin{array}{l}\text { Total GB road } \\
\text { length in miles }\end{array}$ & Annual & Moderator & $\begin{array}{l}\text { (Department for } \\
\text { Transport, 2016c) }\end{array}$ \\
\hline \multirow[t]{3}{*}{$\begin{array}{l}\text { Socio- } \\
\text { economic }\end{array}$} & $\begin{array}{l}\text { Unemployment } \\
\text { rate }\end{array}$ & $\begin{array}{l}\text { Rate of } \\
\text { unemployment per } \\
\text { capita }\end{array}$ & Monthly & Mediator & $\begin{array}{l}\text { (Office of National } \\
\text { Statistics, 2017a) }\end{array}$ \\
\hline & GDP & $\begin{array}{l}\text { Economic growth } \\
\text { per capita }\end{array}$ & Quarterly & Confounder & $\begin{array}{l}\text { (Office of National } \\
\text { Statistics, 2017b) }\end{array}$ \\
\hline & Population & $\begin{array}{l}\text { Population of } 16 \\
\text { plus in thousands }\end{array}$ & Monthly & Moderator & $\begin{array}{l}\text { (Office of National } \\
\text { Statistics, 2018) }\end{array}$ \\
\hline
\end{tabular}




\begin{tabular}{|c|c|c|c|c|c|}
\hline Data Type & Variable & Description & $\begin{array}{l}\text { Available } \\
\text { Frequency }\end{array}$ & Type & Source \\
\hline & Fuel price & $\begin{array}{l}\text { Pump price of } \\
\text { petrol and diesel in } \\
\text { pence per litre }\end{array}$ & Weekly & $\begin{array}{l}\text { Main } \\
\text { independent } \\
\text { variable }\end{array}$ & $\begin{array}{lr}\text { (Department } r \text { for } \\
\text { Business } & \text { Energy } \\
\text { and } & \text { Industrial, } \\
2018) & \end{array}$ \\
\hline \multirow[t]{3}{*}{ Weather } & $\begin{array}{l}\text { Temperature }\left({ }^{0} \mathrm{C}\right. \\
) \text {. }\end{array}$ & $\begin{array}{l}\text { Average minimum, } \\
\text { maximum and } \\
\text { mean temperature } \\
\text { of GB }\end{array}$ & \multirow[t]{3}{*}{ Monthly } & \multirow[t]{3}{*}{ Confounder } & \multirow[t]{3}{*}{ (Met Office, 2017) } \\
\hline & Rainfall (mm) & $\begin{array}{l}\text { Average rainfall of } \\
\text { GB }\end{array}$ & & & \\
\hline & Sunshine hours & $\begin{array}{l}\text { Average sunshine } \\
\text { hours of GB }\end{array}$ & & & \\
\hline $\begin{array}{l}\text { Specific } \\
\text { event }\end{array}$ & $\begin{array}{l}\text { Indicator for the } \\
\text { Christmas } \\
\text { period }\end{array}$ & $\begin{array}{l}\text { Dummy variable } \\
(0,1) \text { to control for } \\
\text { unusual accident } \\
\text { patterns. } 0=51 \text { Not } \\
\text { a Christmas week } \\
1=52 \text { Christmas } \\
\text { week }\end{array}$ & Weekly & Indicator & Manual \\
\hline
\end{tabular}

*Data sources links have been provided in the above Table 2 as and when necessary.

3 Weather data comprising of minimum, maximum, mean temperature, rainfall and sunshine

4 hours was taken from the Met Office weather summaries for each month (Met Office, 2017).

5 One limitation with the data is that values for the whole of Great Britain are not directly

6 available, and so an average of values from England, Scotland and Wales was used instead.

7 According to the Department for Transport, the number of road traffic accidents in Great

8 Britain increases during the summer months with a corresponding decrease in winter

9 (Department of Transport, 2014).

10 One anomaly appears in the data each year for the week around Christmas, which

11 shows a major reduction in accidents (an average of $12 \%$ less weekly accidents) and is

12 possibly due to the combined effects of the holiday and accompanying bad weather.

13 Specifically, daily averages of Christmas Day (25 th of December) and Boxing Day (26 $6^{\text {th }}$ of

14 December) have been found to have 56 percent and 42 percent less total accidents respectively

15 when compared to daily average accident counts. To mitigate the effect of Christmas week a

16 dummy variable for the Christmas week has been introduced. 


\section{METHOD}

3 The purpose of this study is to develop a relationship between fuel price and road traffic

4 accidents while controlling for other related factors for GB. Based upon the available data 5 and other modelling issues appropriate accident prediction methods have been investigated 6 and developed in this study. model which is the equi-dispersion (whereby variance $=$ mean), though this is rarely true for accident count data which is mostly found to be over-dispersed (i.e. variance $>>$ mean). The

11 negative binomial (NB) distribution is therefore the next best choice to deal with the over12 dispersion in the data, and variants have been used in many studies to analyse count data 13 (Noland, 2005). However, whilst Poisson regression or NB regression models and its 14 extensions are useful for analysing cross-sectional data with an assumption that observations are independent of each other and have been used in the previous studies to control serial correlation by introducing a time trend variable (Chi et al., 2013, 2010; Noland and Karlaftis, 2005), these models are not really suitable for time series data and can result in the incorrect estimation of parameters. This is potentially problematic in this case because the accident data

19 used in this study is aggregate-level weekly time series count data for Great Britain from 2005 to 2015 and so could well be serially correlated. Quddus (2008) proposed that when the

21 analysis units of observation (spatial and temporal) are relatively large (e.g. country-wide 22 weekly or monthly traffic collisions) with a high value of the mean count (say greater than 23 50) then the data is termed as highly aggregated time-series data. Therefore, addressing the 24 inherent serial correlation is more important than preserving the properties of count data (e.g. 
1 the Poisson or NB process). Hence statistical models suitable for controlling serial correlation

2 are considered in this study.

There are many different statistical models that are used in handling serial

4 autocorrelation. In safety analysis, two models have primarily been used: (i) Prais-Winsten

5 AR(1) model (Chi et al., 2010) and (ii) ARIMA models and their extensions (Hyatt et al.,

6 2009). First, the Prais-Winsten regression model is able to account for any serial correlation

7 present in a time series dataset but is more complex. These models estimate through a

8 generalized linear square (GLS) regression function and can be used to transform a data series

9 to resolve the issues of first order autoregressive (AR1) correlation which makes the residual

10 stationary resulting in more reliable and accurate predictions. The important statistic to look

11 for here is the Durbin-Watson $d$-value. The value of ' $d$ ' statistics should be between $0-4$,

12 where 0 indicates a perfect negative correlation, a value equals to 2 represents no

13 autocorrelation and a value moving towards 4 means a positive correlation.

$15 \Upsilon_{t}=\beta_{o}+\sum_{j=1}^{k} \beta_{j} X_{j t}+\mu_{t}$ where $\mu_{t}=\rho \mu_{t-1}+e_{t}$

$17 \Upsilon_{t}=$ Number of weekly crashes in time ' $t$ '

$18 \mu_{t}=$ model error term; where $t=1, \ldots . ., \mathrm{n}$

$19 \quad \mathrm{X}_{j t}=$ Vector of explanatory variables

$20 k=$ Number of explanatory variables

$21 \rho=$ Autocorrelation coefficient of order 1 (i.e. AR1) and $\rho=1$ means that there is a perfect

22 correlation among residuals ('perfect' means residuals are identical);

$23 \beta_{\mathrm{o}}, \beta_{\mathrm{j}}=$ Parameters to be estimated;

$24 e_{t}=$ Refers to the independently and identically distributed error term with zero-mean and 25 constant variance. 
The second approach is to use time series modelling introduced by Box and Jenkins

3 (1970) which have been used in the last few years to analyse road safety data as compared to

4 cross-sectional studies historically (Box and Jenkins, 2008; Lavrenz et al., 2018). These are

5 well developed and these autoregressive integrated models (ARIMA) and so-called seasonal

6 autoregressive integrated models (SARIMA) have been effectively used to estimate and

7 forecast time series data. Subsequently they were extended to study the effects of exogenous

8 variables on time series along with trend and seasonality (Box and Tiao, 1975).

As mentioned earlier, this study has time series count data which consists of dependent

10 accident variable and independent time series of different control variables, and due to the

11 presence of serial correlation in the series negative binomial models are unsuitable to use in

12 this analysis. To deal with the problem of autocorrelation, dependencies of adjacent values in

13 the time series data, and seasonality-periodic behaviour of the series- ARIMA and SARIMA

14 models have been used in this study.

15 Overall then, the time series model can be defined as:

16

$17 y_{t}=\beta x_{t}+\mathrm{N}_{t}$

19 In cases in which $t$ is the discrete time (week in this case), $y_{t}$ is the appropriate Box-Cox 20 transformation of $y_{t}$, say in $\log y_{t}, y_{t}{ }^{2}$ or $y_{t}$ itself (Box and Cox, 1964), $y_{t}$ is the dependant 21 variable (i.e. accident counts/frequency) for a particular time $t, \beta X$ is the deterministic part 22 of the equation which to account for the effects of independent control variables $(\mathcal{X})$ and $\mathrm{N}_{t}$ 23 is the stochastic or noise component. The stochastic or noise component $\mathrm{N}_{t}$ is $\operatorname{ARIMA}(\mathrm{p}, \mathrm{d}, \mathrm{q})$ 
1 and SARIMA $(\mathrm{p}, \mathrm{d}, \mathrm{q})(\mathrm{P}, \mathrm{D}, \mathrm{Q})_{\mathrm{S}}$ where $p$ is the order of the non-seasonal ${ }^{1}$ autoregressive (AR)

2 process, $d$ is the order of the non-seasonal difference, $q$ is the order of the non-seasonal 3 moving average (MA) process and $P$ is the order of the seasonal autoregressive (AR) process,

$4 \quad D$ is the order of the seasonal difference, $Q$ is the order of the seasonal moving average (MA) 5 process and subscript 's' represents the periodicity or length of seasonality (in this weekly 6 study $\mathrm{s}=52)$.

7

$8 \quad \mathrm{~N}_{t}=\frac{\theta(\mathrm{B}) \Theta(\mathrm{B}) u t}{\emptyset(B) \Phi(B s)(1-B) d(1-B s) D}$

10 Equation (3) is mathematical representation of SARIMA model where " $\emptyset$ " and $\Phi$ are non11 seasonal and seasonal AR components and $\theta$ and $\Theta$ are seasonal and non-seasonal MA 12 components, B and Bs represents backward shift operator, ut is uncorrelated random term 13 with zero mean and constant variance $\sigma 2$. This study ran two types of models: one for petrol fuel prices and the other for diesel fuel prices, for each type of accident severity (fatal, serious and slight). This study developed weekly accident models for all accident severity levels.

\section{FINDINGS}

19 Two separate models were developed: (i) petrol and (ii) diesel. This was necessary due to the 20 high correlation between diesel and petrol prices which meant that it was not possible to 21 include both variables in the same model (see section 5.2 for more details). Each of the models

\footnotetext{
1 'Non-seasonal' means that a term relates to every consecutive observation whereas 'Seasonal' means that a term relates to the seasonal length of 52 weeks in our study
} 
1 has been further classified into three accident categories of fatal, serious and slight accidents.

2 For ease of interpretation of the model coefficients, all three dependent variables were

3 transformed into a logarithmic scale. Since the models are based on a time-series regression,

4 a stationarity test is necessary before conducting the regression analysis. A stationarity test

5 of a dependent variable is required as Granger and Newbold (1974) postulated that regression

6 models for non-stationary variables give spurious results. Stationarity of time series is

7 examined by the commonly employed Dickey-Fuller of Augmented Dickey-Fuller Unit Root

8 Test (Dickey and Fuller, 1979). The results are presented in Table 3. As can be seen, the null

9 hypothesis of a unit root at all common significance level (i.e. $1 \%, 5 \%$ and $10 \%$ ) can be

10 overwhelmingly rejected, confirming that the dependent variables are stationary.

11 TABLE 3: Stationarity Test for Unit Root

\begin{tabular}{|l|l|l|l|l|}
\hline Dependent Variable & $\begin{array}{l}\text { Test Statistic } \\
\mathbf{Z}(\mathbf{t})\end{array}$ & $\begin{array}{l}\mathbf{1 \%} \text { Critical } \\
\text { Value }\end{array}$ & $\begin{array}{l}\mathbf{5 \%} \text { Critical } \\
\text { Value }\end{array}$ & $\begin{array}{l}\mathbf{1 0 \%} \text { Critical } \\
\text { Value }\end{array}$ \\
\hline $\operatorname{Ln}$ (weekly fatal accidents) & -10.551 & -3.430 & -2.860 & -2.570 \\
\hline $\operatorname{Ln}$ (weekly serious accidents) & -10.574 & -3.430 & -2.860 & -2.570 \\
\hline $\operatorname{Ln}$ (weekly slight accidents) & -8.306 & -3.430 & -2.860 & -2.570 \\
\hline
\end{tabular}

12

13

14

15

16

17

18

19

20

21 Bayesian Information Criterion, BIC), the optimal specification for the ARIMA model was

Overall 12 different accident models were applied: two separate modelling techniques (Prais-Winsten AR(1) model and seasonal ARIMA); were applied to two different fuel types (diesel and petrol); at three different accident levels (fatal, serious and slight). All explanatory variables shown in Table 2 were initially included in the models but only the statistically significant variables were retained in the final models. Table 4 shows descriptive statistics for the variables that appeared in the final models. The exception here was 'rainfall', which is only significant for the fatal accident model and therefore was removed from the other accident models. Based on the model goodness of fit (i.e. Schwarz Information Criterion or found to be SARIMA $(0,0,1)(0,0,1)_{52}$ with 1 non-seasonal and 1 seasoanl MA terms. 
Table 5 presents the modelling results for all the models. Since each of the dependent

2 variables were transformed into the logarithmic scale, the coefficient values in Table 5

3 indicate 'elasticities' rather than 'slope coefficients' for the continuous explanatory variables.

4 Although Prais-Winsten AR(1) models controlled for serial correlation through an

5 autoregressive term of order 1 and SARIMA models controlled it through two moving

6 average terms (one non-seasonal of order 1, MA1 and one seasonal of order 1, SMA1), the

7 results are identical with respect to the set of statistically significant variables and the

8 magnitudes of the estimated parameters. Since the Prais-Winsten AR(1) model is more

9 parsimonious, the interpretation of the results is primarily based on this model. All Durban-

10 Watson d-statistic values from the Prais-Winsten models have found to be close to 2 which

11 indicates that the models have been successful in controlling serial correlation in the data.

13 TABLE 4 Descriptive Statistics of Variables Used in the Statistical Analysis*

\begin{tabular}{|l|l|l|l|l|l|}
\hline Variable & Mean & Variance & Std. Dev. & Min. & Max. \\
\hline $\begin{array}{l}\text { Weekly total accident } \\
\text { counts }\end{array}$ & 3,086 & $264,736.51$ & 514.53 & 1589 & 4,519 \\
\hline $\begin{array}{l}\text { Weekly fatal accident } \\
\text { counts }\end{array}$ & 40 & 160.72 & 12.67 & 16 & 75 \\
\hline $\begin{array}{l}\text { Weekly serious } \\
\text { accident counts }\end{array}$ & 419 & $4,556.17$ & 67.50 & 162 & 588 \\
\hline $\begin{array}{l}\text { Weekly slight accident } \\
\text { counts }\end{array}$ & 2,627 & $201,483.00$ & 448.87 & 1305 & 3,930 \\
\hline $\begin{array}{l}\text { Weekly petrol price } \\
\text { (pence per litre) }\end{array}$ & 112.58 & 328.07 & 18.11 & 78.93 & 142.17 \\
\hline $\begin{array}{l}\text { Weekly diesel price } \\
\text { (pence per litre) }\end{array}$ & 117.68 & 355.90 & 18.86 & 83.87 & 148.04 \\
\hline $\begin{array}{l}\text { GB population aged } 16 \\
\text { and over (million) }\end{array}$ & 48.73 & 1.59 & 1.26 & 46.45 & 50.81 \\
\hline \begin{tabular}{l} 
Cars VMT (billions) \\
\hline
\end{tabular} & 179.96 & 102.129 & 10.11 & 153.57 & 199.00 \\
\hline
\end{tabular}




\begin{tabular}{|l|l|l|l|l|l|}
\hline Variable & Mean & Variance & Std. Dev. & Min. & Max. \\
\hline Rainfall (mm) & 110.96 & $2,304.104$ & 48.00 & 23.6 & 265.63 \\
\hline
\end{tabular}

*There are 572 total observations for each variable included in the above.

\section{$3 \quad$ 5.1 Fuel Price and Accident Frequency}

4 One of the key objectives is to investigate how fuel price changes affect road accident

5 frequency while controlling for related factors. From Figure 3 a trend is noticeable that across

6 the decade 2005-2015 there was a broadly negative relationship between fuel price and the

7 number of road accidents. Thus, between 2005 and 2007 when fuel prices were relatively low

8 there was an increase in road traffic accidents whilst during 2009 to 2012 when prices rose

9 there was a corresponding reduction in accidents.

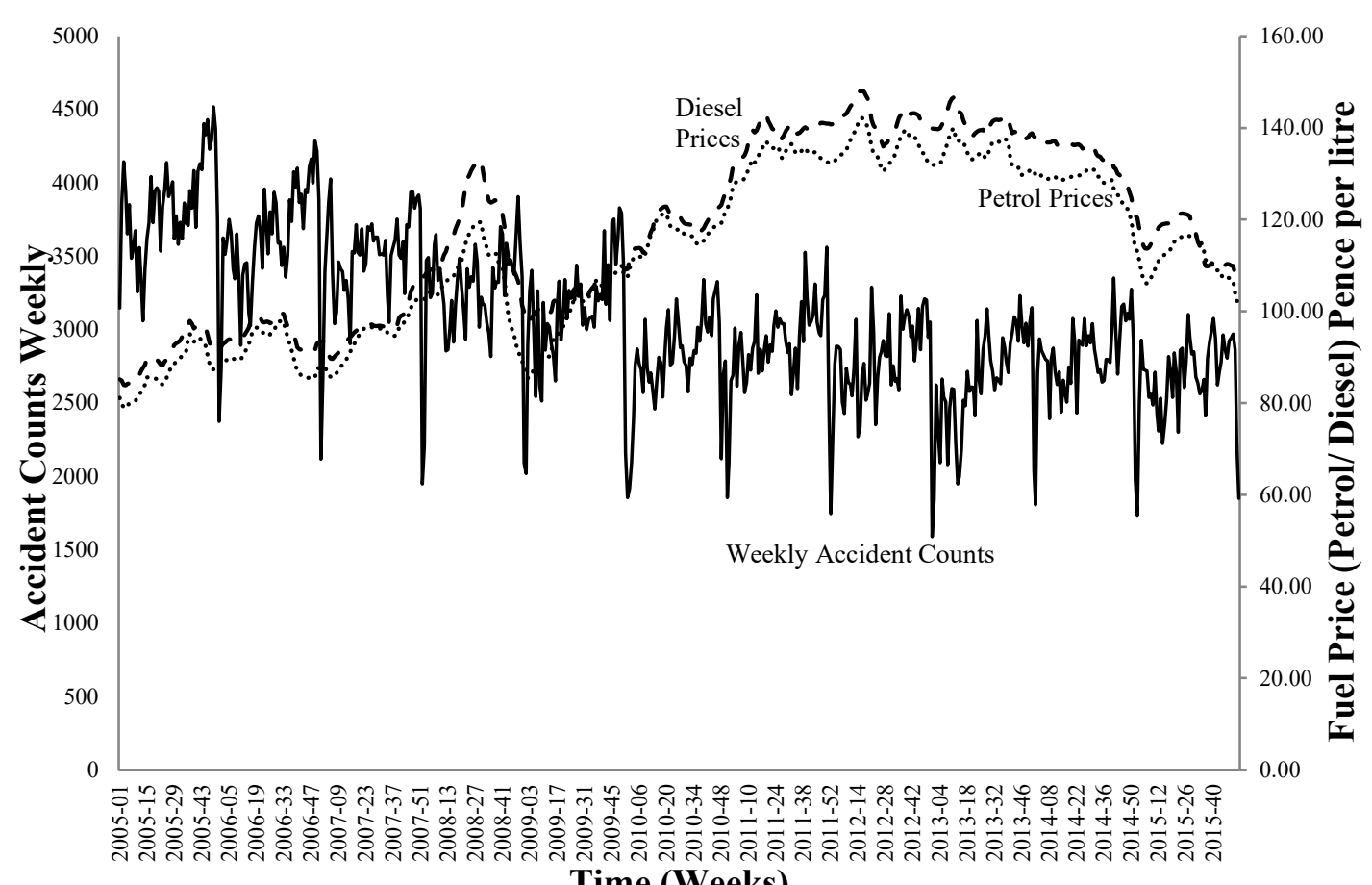

11 FIGURE 3 Fuel Price and Accident Frequency (GB 2005-2015) 
This negative relationship is clearly reflected in our results for both the diesel and petrol model analyses, such that fuel prices were linked to the number of fatal accidents by an elasticity value of ' -0.45 and '- 0.39 ' respectively i.e. that for every $1 \%$ increase in fuel price, the number of fatal accidents fell by $0.4 \%$ (see Table 5). These results have been obtained at the mean price values of petrol and diesel, which were 112.58 pence per litre and 117.68 pence per litre respectively. These results are consistent with the previous studies that analysed fuel price and accident rate/ fatalities rate in other parts of the world (Chi et al., 2017; Grabowski and Morrisey, 2004) suggesting that fuel prices do affect road safety through a reduction in fatalities which is an important road safety target around the world. In understanding this, there seem to be two major possible links through which fuel prices affect accidents; through changes in driver behaviour, and through changes in exposure. In terms of driver behaviour, in the short term, one might expect to see drivers slowing down, and driving more smoothly in order to use less fuel which could also help lead to less accidents (Wolff, 2014). In terms of exposure meanwhile, drivers will likely seek to reduce the money they spend on fuel, and thus reduce their VMT, and this could play out in several ways. In the short term, drivers might change their route to minimise distance, congestion, or stopping and starting (route assignment); switch modes for certain trips - i.e. walk, cycle, use 19 public transport, or share their cars with other people (mode choice); start trip chaining, reducing peak period trips by car, or travel to/from activities that are closer to home (trip 21 distribution); or replace trips altogether by working at home or shopping on-line (trip generation). In the longer term, some drivers might be expected to change their vehicles to be more fuel efficient or to a 'cleaner' power source; and to move their job and/or their house so

24 as to reduce the distance they have to travel and the money they spend on fuel. With regard to exposure, it is important to understand that such changes will likely impact different groups 
1 and different geographical areas in different ways. For example, higher fuel prices will

2 probably disproportionately deter many younger people from driving and thus reduce the

3 number of people from this 'risky driver' group on the roads and stop accidents from

4 happening (Department for Transport, 2015a). Geographically too there are differences,

5 whereby rural drivers have been shown to be more sensitive to fuel price changes than urban

6 drivers (Chi et al, 2013), which in the Great Britain context has been where most accidents

7 occur due to greater speed variability and poorer road conditions (Department of Transport,

8 2015).

9

\section{$10 \quad 5.2$ Comparison of Petrol and Diesel Models}

11 There has been a decline in the number of petrol cars over the study period (2005-2015) in

12 Great Britain from 21.8 million (79.5\% of total cars) to 18.1 million (61.2\%) in 2015 (see

13 Figure 4). At the same time, the number of diesel cars numbers grew from 5.6 million (20.3

$14 \%$ of total cars) in 2005 to 11.4 million (36.2\% of total cars) in 2015.

15

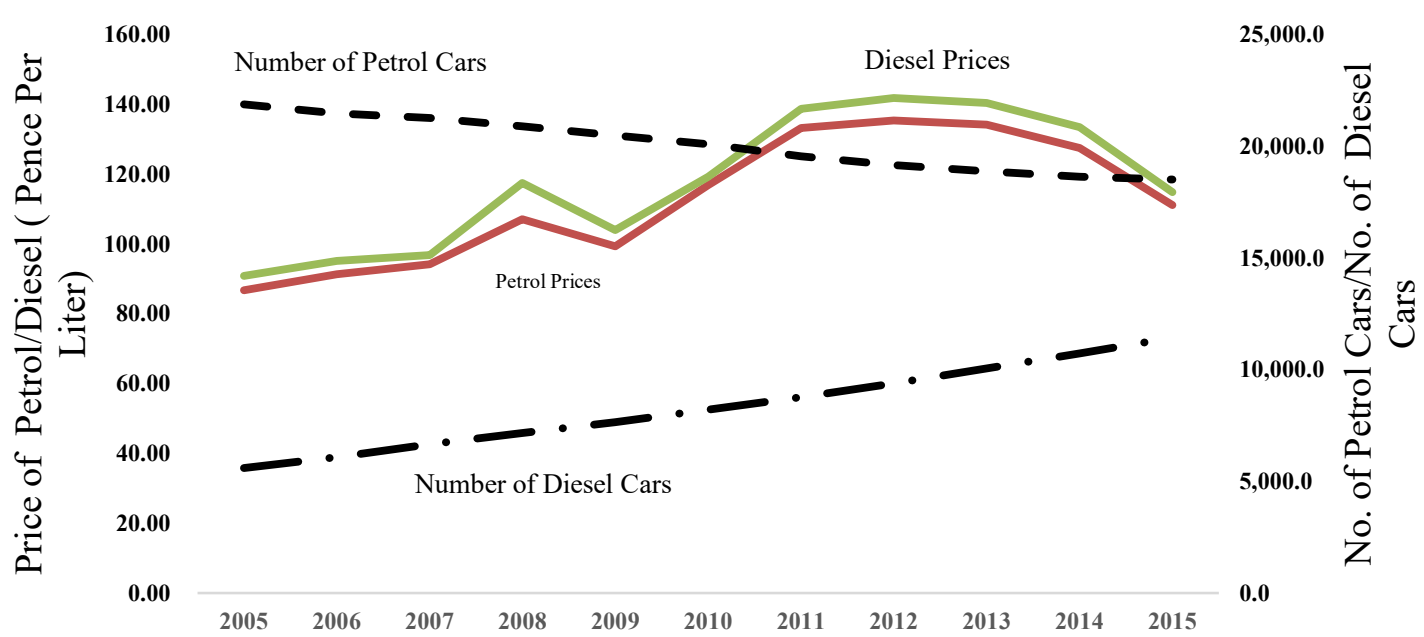

16

Time (Years)

17 FIGURE 4 Changes in Numbers of Cars Based Upon Fuel Type 
1 This shift was driven due to the better fuel efficiency and carbon emission performance of

2 diesel vehicles (Department for Transport, 2015), and was encouraged by Government tax

3 policy on $\mathrm{CO}_{2}$ reduction which subsidised diesel fuel cars from 2001. However, increased

4 public health concerns (especially in children) caused by poor local air quality, have seen a

5 recent policy switch away from incentivising the use of diesel powered vehicles, which have

6 largely generated the increased levels of nitrogen dioxide $\mathrm{NO}_{2}$ and particulates. Accident elasticities from both these separate models are shown in Table 5. The

8 elasticity value remains approximately the same, with the slightly higher value for petrol

9 elasticity perhaps being due to there being more petrol cars on British roads. Thus, both model

10 results can be interpreted such that the fuel price effects on accidents remains negative i.e.

11 that a $1 \%$ increase in fuel price will reduce road traffic accidents by $0.45 \%$ for petrol price 12 and $0.39 \%$ for diesel at the $95 \%$ confidence interval. 
TABLE 5 Modelling Results: Prais -Winsten AR(1) Model and SARIMA $(0,0,1)(0,0,1)_{52}$ Model

\begin{tabular}{|c|c|c|c|c|c|c|c|c|c|c|c|c|}
\hline \multicolumn{13}{|c|}{ Prais-Winsten AR(1) model } \\
\hline \multicolumn{7}{|c|}{ Petrol model } & \multicolumn{6}{|c|}{ Diesel model } \\
\hline \multirow{2}{*}{$\begin{array}{l}\text { Dependent } \\
\text { variable: } \\
\text { ln(weekly } \\
\text { accidents inGB) }\end{array}$} & \multicolumn{2}{|c|}{ Fatal } & \multicolumn{2}{|c|}{ Serious } & \multicolumn{2}{|c|}{ Slight } & \multicolumn{2}{|c|}{ Fatal } & \multicolumn{2}{|c|}{ Serious } & \multicolumn{2}{|c|}{ Slight } \\
\hline & Coefficient & t-stat & Coefficient & t-stat & Coefficient & t-stat & Coefficient & t-stat & Coefficient & t-stat & Coefficient & t-stat \\
\hline $\ln ($ petrol price $)$ & -0.453 & -4.04 & 0.021 & -0.23 & -0.119 & -1.20 & -0.391 & -3.45 & 0.000 & 0.00 & -0.127 & -1.28 \\
\hline $\ln ($ car VMT $)$ & 1.094 & 5.58 & 1.188 & 7.83 & 0.341 & 2.21 & 1.048 & 5.23 & 1.189 & 7.79 & 0.327 & 2.11 \\
\hline $\ln ($ population) & -6.326 & -8.88 & -3.030 & -5.18 & -3.991 & -6.31 & -6.671 & -9.34 & -3.136 & -5.43 & -3.962 & -6.34 \\
\hline $\ln$ (rainfall) & 0.050 & 2.16 & - & - & - & - & 0.052 & 2.21 & - & - & - & - \\
\hline Christmas & 0.153 & 2.53 & 0.081 & 2.36 & 0.110 & 4.01 & 0.153 & 2.55 & 0.081 & 2.36 & 0.110 & 4.01 \\
\hline Constant & 24.433 & 9.75 & 11.725 & 5.68 & 22.155 & 9.97 & 25.731 & 10.41 & 12.036 & 6.01 & 22.156 & 10.25 \\
\hline $\begin{array}{l}\text { Correlation } \\
\text { coefficient, } \rho\end{array}$ & \multicolumn{2}{|c|}{0.239} & \multicolumn{2}{|c|}{0.443} & \multicolumn{2}{|c|}{0.568} & \multicolumn{2}{|c|}{0.250} & \multicolumn{2}{|c|}{0.443} & \multicolumn{2}{|c|}{0.569} \\
\hline \multicolumn{13}{|c|}{ Seasonal ARIMA models $(0,0,1)(0,0,1)_{52}$} \\
\hline \multicolumn{7}{|c|}{ Petrol model } & \multicolumn{6}{|c|}{ Diesel model } \\
\hline \multirow{2}{*}{$\begin{array}{l}\text { Dependent } \\
\text { variable: } \\
\text { ln(weekly } \\
\text { accidents in GB) }\end{array}$} & \multicolumn{2}{|c|}{ Fatal } & \multicolumn{2}{|c|}{ Serious } & \multicolumn{2}{|c|}{ Slight } & \multicolumn{2}{|c|}{ Fatal } & \multicolumn{2}{|c|}{ Serious } & \multicolumn{2}{|c|}{ Slight } \\
\hline & Coefficient & t-stat & Coefficient & t-stat & Coefficient & t-stat & Coefficient & t-stat & Coefficient & t-stat & Coefficient & t-stat \\
\hline $\ln ($ petrol price $)$ & -0.437 & -3.95 & -0.025 & -0.31 & -0.094 & -1.54 & -0.368 & -3.26 & 0.003 & 0.04 & -0.102 & -1.57 \\
\hline $\ln ($ car VMT $)$ & 1.129 & 5.69 & 1.329 & 9.39 & 0.605 & 4.90 & 1.091 & 5.44 & 1.333 & 9.38 & 0.5918 & 4.78 \\
\hline $\ln$ (population) & -6.411 & -8.89 & -3.049 & -5.37 & -4.231 & -9.35 & -6.789 & -9.29 & -3.187 & -5.51 & -4.203 & -9.08 \\
\hline $\ln$ (rainfall) & 0.053 & 2.48 & - & - & - & - & 0.0561 & 2.59 & - & - & - & - \\
\hline Christmas & 0.161 & 3.48 & 0.072 & 3.40 & 0.103 & 6.78 & 0.162 & 3.54 & 0.073 & 3.42 & 0.102 & 6.74 \\
\hline Constant & 24.497 & 9.59 & 11.088 & 5.49 & 21.604 & 12.81 & 25.837 & 10.07 & 11.47177 & 5.67 & 21.602 & 12.74 \\
\hline
\end{tabular}




\subsection{Variables selected for the final model:}

Throughout the literature, fuel price has been conceptualized to affect accidents e.g. through changes in factors such as vehicle miles travelled (VMT), changes in fuel consumption through less travel and more rational driving behaviour etc. In this study, VMT has been used as an exposure variable and car VMT are found to be significant for fatal accidents model (elasticity value $=1.09$ ) which is consistent with the previous literature and explains that changes in fuel prices can affect changes in accidents through variation in VMT. GDP has not been found statistically significant in this study and was thus excluded from the final models. The population of an area can affect number of accidents through increased travel demand (Department for Transport, 2013), and therefore population of all 16 plus of GB residents was included in the model. It is to a certain degree surprising that population has a negative association with all types of road traffic accidents. This is because an increase in population indicates more travel activities and therefore a positive association is expected. While this may be true for cross-sectional data, population represents 'trend' in time-series analysis of accidents. This is evident as population has steadily increased over the study period in GB while traffic accidents have decreased during the same period. Rainfall was used as the most influential weather control variable and was found to be a statistically significant predictor affecting fatal accidents only as in rainfall becomes insignificant for other types of accidents (serious and slight) and therefore, removed from those models. More specifically, a 1\% increase in rainfall will increase fatal accidents by $0.05 \%$.

\section{DISCUSSION AND CONCLUSION}

A reduction in road accident fatalities around the world has previously been linked with the economic downturn (Interenational Transport Forum, 2015). In the British case, an additional explanation for this is the parallel trend in fuel prices, whereby petrol and diesel became more 
expensive during the recession period of 2008-2010 (Department for Transport, 2015b). This paper is original in that whilst there is international evidence on the accident and fuel price relationship, so far there have not been any studies on this topic in coutries with relatively high fuel prices. Thus, fuel prices in Great Britain are impacted through the implementation of relatively high rates of fuel duty and fuel tax (VAT on top of duty). They are the $11^{\text {th }}$ highest for petrol and $3^{\text {rd }}$ highest for diesel in the whole of the EU (May, 2018), and are double those in the USA.

This formed the rationale for an investigation on how much accidents have been controlled through fuel prices in Great Britain and hence is the focus of this paper. The rigour of the method was derived from applying two separate modelling techniques (Prais-Winsten AR(1) model and seasonal ARIMA); to two different fuel types (diesel and petrol); at three different accident levels (fatal, serious and slight); to weekly national-level data collected over the course of a decade.

The study found that fuel prices are only significant for fatal accidents and not for serious and slight accidents. Changing fuel prices affected fatal road accidents not only during recession but also throughout the whole time period of the study from 2005 to 2015 . The petrol and diesel price levels were found to have almost the same negative effect on fatal accidents. In addition, two different statistical models were applied to the same data, but an almost identical impact was obtained. This ensures an efficacy of the findings. Increase in fuel price perhaps captures changes in exposure and driving behaviours of motorists through reducing speed, travelling less and a reduction in the 'risky driver' population.

Finally, this study is significant in that it lays the foundation of future road safety policy and practice by proving an evidence regarding the significance of fuel price in the GB in mitigating road traffic accidents. This is important because high fuel taxes are seen as being a core policy tool that aims to reduce air and noise pollution, congestion and road accidents 
through a reduction in traffic exposure, whilst part of the revenue generated from the fuel taxes is spent on road safety improvement projects. Moreover, the changing composition of the vehicle fleet from fossil fuelled engines to hybrid and electric cars and the corresponding loss of tax revenue could lead to more road safety issues, and possibly to more road accidents than currently. Fundamentally, this evidence can help policy makers to better understand the implications of fuel price policy on road accidents, and to devise new and better transport pricing policies in the near future for controlling fatal accidents that are currently supressed by high fuel prices.

\section{REFERENCES}

- Ahmad, S., Greene, D., 2005. Effect of Fuel Economy on Automobile Safety: A Reexamination. Transp. Res. Rec. 1941 1 , 1-7. doi:10.3141/1941-01

- Bauman, A.E., Sallis, J.F., Dzewaltowski, D.A., Owen, N., 2002. Toward a better understanding of the influences on physical activity: The role of determinants, correlates, causal variables, mediators, moderators, and confounders. Am. J. Prev. Med. 232 SUPPL. 1 , 5-14. doi:10.1016/S07493797(02)00469-5

- BBC, 2017. UK, New diesel and petrol vehicles to be banned from 2040 in UK.

- Bishai, D., Quresh, A., James, P., Ghaffar, A., 2006. National road casualties and economic development. Health Econ. 15 1, 65-81. doi:10.1002/hec.1020

- Blincoe, L., Miller, T.R., Zaloshnja, E., 2015. Date 6. Performing Organization Code 7. Authors.

- Blomquist, G., 1984. The 55 m.p.h speed limit and gasoline consumption. Resour. Energy 6 1, 21-39. doi:10.1016/S0165-0572(84)80003-1

- Box, G.E.P., Cox, ; D R, 1964. An Analysis of Transformations. J. R. Stat. Soc. Ser. B 262 , 211-252.

- Box, G.E.P., Tiao, ; G C, 1975. Intervention Analysis with Applications to Economic and Environmental Problems. J. Am. Stat. Assoc. 70349 , 70-79.

- Burger, N.E., Kaffine, D.T., 2015. GAS PRICES , TRAFFIC, AND FREEWAY SPEEDS IN LOS ANGELES Author ( s ): Nicholas E . Burger and Daniel T . Kaffine Published by : MIT Press Stable URL : http://www.jstor.org/stable/25651365 Your use of the JSTOR archive indicates your acceptance of the Ter $913,652-657$.

- Burke, P.J., Nishitateno, S., 2015. Gasoline Prices and Road Fatalities: International Evidence. Econ. Inq. 533 , 1437-1450. doi:10.1111/ecin.12171

- Busse, M., Knittel, C., Zettelmeyer, F., 2009. Pain at the Pump: The Differential Effect of Gasoline Prices on New and Used Automobile Markets 1-56. doi:10.3386/w15590 
- $\quad$ Chi, G., Brown, W., Zhang, X., Zheng, Y., 2015. Safer Roads Owing to Higher Gasoline Prices : How Long It Takes. Am. J. Public Health 1058 , 119-125. doi:10.2105/AJPH.2015.302579

- Chi, G., Cosby, A.G., Quddus, M.A., Gilbert, P.A., Levinson, D., 2010. Gasoline prices and traffic safety in Mississippi. J. Safety Res. 41 6,493-500. doi:10.1016/j.jsr.2010.10.003

- Chi, G., Mcclure, T., Boydstun, J., 2017. Gasoline Price Changes and Residential Relocation : Evidence from the American Housing Survey, 1995 - 2009.

- Chi, G., Quddus, M. a., Huang, A., Levinson, D., 2013. Gasoline price effects on traffic safety in urban and rural areas: Evidence from Minnesota, 1998-2007. Saf. Sci. 59, 154-162. doi:10.1016/j.ssci.2013.05.012

- $\quad$ Chi, G.Q., McClure, T.E., Brown, D.B., 2012. Gasoline Prices and Traffic Crashes in Alabama, 19992009. Traffic Inj. Prev. 135 , 476-484. doi:10.1080/15389588.2012.670815

- Currie, G., Phung, J., 2007. Transit Ridership, Auto Gas Prices, and World Events: New Drivers of Change? Transp. Res. Rec. J. Transp. Res. Board 1992, 3-10. doi:10.3141/1992-01

- Department for Business Energy and Industrial, 2018. Weekly road fuel prices. https://www.gov.uk/government/statistical-data-sets/oil-and-petroleum-products-weekly-statistics

- Department for Transport, 2018. Reported road casualties in Great Britain: quarterly provisional estimates year ending September 2017.

- Department for Transport, 2017. Reported road casualties in Great Britain: quarterly provisional estimates year ending September 2016.

- Department for Transport, 2016a. Reported Road Casualties Great Britain: 2015 Annual Report (2016).

- Department for Transport, 2016b. Reported road casualties in Great Britain: quarterly provisional estimates Year ending September 2015.

- Department for Transport, 2016c. Road lengths in Great Britain: 2015 [WWW Document].

- Department for Transport, 2015a. Reported road casualties Great Britain: annual report 2014, National Statistics, Department for Transport.

- Department for Transport, 2015b. Factors affecting reported road casualties.

- $\quad$ Department for Transport, 2013. Road Transport Forecasts 2013. Forecast 1-12.

- Department for Transport, n.d. STATS19 Personal Injury Road Accidents in GB, 2005-2015, Road Safety Data, DfT, London. 2015. https://data.gov.uk/dataset/cb7ae6f0-4be6-4935-927747e5ce24a11f/road-safety-data

- Department for Transport, 2015. Department of Transport, Vehicle Licencing Statistics, Quarter 3 (JulSep) 2015, December 2015.

- Department for Transport (2015), 2017. Provisional road traffic estimates, Great Britain: 20052015,DfT, London.

- Department of Transport, 2015. Facts on Road Fatalities.Department of Transport, 2014. Reported Road Casualties in Great Britain: Main Results 2013. Statistical Release.

- Dickey, D. A., and W. A. Fuller. 1979. Distribution of the estimators for autoregressive time series with a unit root. Journal of the American Statistical Association 74: 427-431.

- Elvik, R., 2013. A re-parameterisation of the Power Model of the relationship between the speed of traffic and the number of accidents and accident victims. Accid. Anal. Prev. 50, 854-860. 
doi:10.1016/j.aap.2012.07.012

- $\quad$ Elvik, R., 2003. Assessing the validity of road safety evaluation studies by analysing causal chains. Accid. Anal. Prev. 35 5 , 741-748. doi:10.1016/S0001-4575(02)00077-5

- $\quad$ Fridstrøm, L., Ifver, J., Ingebrigtsen, S., Kulmala, R., Thomsen, L.K., 1995. Measuring the contribution of randomness, exposure, weather, and daylight to the variation in road accident counts. Accid. Anal. Prev. 27 1 , 1-20. doi:10.1016/0001-4575(94)E0023-E

- George E.A. Box, Gwilym M. Jenkins, G.C.R., 2008. Time Series Analysis: Forcasting and Control, Fourth. ed. John Wiley and Sons, New Jersey.

- Goodwin, P., Dargay, J., Hanly, M., 2004. Elasticities of Road Traffic and Fuel Consumption with Respect to Price and Income: A Review Elasticities of Road Traffic and Fuel Consumption with Respect to Price and Income : A Review 1647 January . doi:10.1080/0144164042000181725

- Grabowski, D.C., Morrisey, M.A., 2004. Gasoline prices and motor vehicle fatalities. J. Policy Anal. Manag. 23 , 575-593. doi:10.1002/pam.20028

- Grabowski, D.C., Morrisey, M.A., 2004. Gasoline Prices and Motor Vehicle Fatalities. J. Policy Anal. Manag. 23 , 575-593. doi:10.1002/pam.20028

- Graham, D.J., Glaister, S., 2004. Road Traffic Demand Elasticity Estimates: A Review. Transp. Rev. 243 , 261-274. doi:10.1080/0144164032000101193

- Granger, C.W.J. and Newbold, P. (1974) Spurious Regressions in Econometrics, Journal of Econometrics 2, 111-120.

- Haire, A., Machemehl, R., 2007. Impact of Rising Fuel Prices on U.S. Transit Ridership. Transp. Res. Rec. J. Transp. Res. Board 1992, 11-19. doi:10.3141/1992-02

- Hyatt, E., Griffin, R., Rue, L.W., McGwin, G., 2009. The association between price of regular-grade gasoline and injury and mortality rates among occupants involved in motorcycle- and automobilerelated motor vehicle collisions. Accid. Anal. Prev. 415 , 1075-1079. doi:10.1016/j.aap.2009.06.009

- Interenational Transport Forum, 2015. Why Does Road Safety Improve When Economic Times Are Hard?

- Jokscfi, H.C., 1984. Accident Deaths and Economic Activity 163 .

- Kamangar, F., 2012. Confounding variables in epidemiologic studies: Basics and beyond. Arch. Iran. Med. 158 , 508-516. doi:012158/AIM.0014

- $\quad$ Lavrenz, S.M., Vlahogianni, E.I., Gkritza, K., Ke, Y., 2018. Time series modeling in traffic safety research. Accid. Anal. Prev. 117, 368-380. doi:10.1016/j.aap.2017.11.030

- $\quad$ Met Office, 2017. Climate Summaries :2005-2015.

- Musso, A., Piccioni, C., Tozzi, M., Godard, G., Lapeyre, A., Papandreou, K., 2013. Road Transport Elasticity: How Fuel Price Changes can Affect Traffic Demand on a Toll Motorway. Procedia - Soc. Behav. Sci. 87, 85-102. doi:10.1016/j.sbspro.2013.10.596

- Noel, D., David, H., Cassie, B., 2016. Petrol and diesel prices 04712 , 25. doi:SN/SG/4712

- Noland, R.B., 2005. Fuel economy and traffic fatalities: multivariate analysis of international data. Energy Policy 3317 , 2183-2190. doi:10.1016/j.enpol.2004.04.016

- Noland, R.B., Karlaftis, M.G., 2005. Sensitivity of crash models to alternative specifications. Transp. 
Res. Part E Logist. Transp. Rev. 415 , 439-458. doi:10.1016/j.tre.2005.03.002

- Office of National Statistics, 2018. LFS: Population aged 16 and over: Great Britain: All: Thousands: NSA.https://www.ons.gov.uk/employmentandlabourmarket/peopleinwork/employmentandemployeet ypes/timeseries/ycho/lms

- Office of National Statistics, 2017a. LFS: Economic inactivity rate: Aged 16-64: GB: All: \%: SA https://www.ons.gov.uk/employmentandlabourmarket/peoplenotinwork/economicinactivity/timeserie $\mathrm{s} / \mathrm{lf} 4 \mathrm{t} / \mathrm{lms}$

- Office of National Statistics, 2017b. Gross Domestic Product Estimate 2005-2015 https://www.ons.gov.uk/search?q=Gross+domestic+product+\%28Average $\% 29+$ per + head $\% 2 \mathrm{C}+\mathrm{CVM}$ + market + prices $\% 3 \mathrm{~A}+\mathrm{SA}$

- Parry, I., 2001. Are gasoline taxes in Britain too high? Challenge 444 , 67-81. doi:10.1080/05775132.2001.11034108

- Quddus, M. a, 2008. Time series count data models: an empirical application to traffic accidents. Accid. Anal. Prev. 405 , 1732-41. doi:10.1016/j.aap.2008.06.011

- Quddus, M.A., 2008. Time series count data models: An empirical application to traffic accidents. Accid. Anal. Prev. 40 5 , 1732-1741. doi:10.1016/j.aap.2008.06.011

- Rodríguez-López, J., Marrero, G.A., González, R.M., Leal-Linares, T., 2016. Road accidents and business cycles in Spain. Accid. Anal. Prev. 96, 46-55. doi:10.1016/j.aap.2016.07.029

- Santos, G., Behrendt, H., Maconi, L., Shirvani, T., Teytelboym, A., 2010. Part I: Externalities and economic policies in road transport. Res. Transp. Econ. 28 1, 2-45. doi:10.1016/j.retrec.2009.11.002

- The Society of Motor Manufacturers and Traders (SMMT), 2018. UK new car registrations. https://www.smmt.co.uk/?s=new+car+registration+in+the+uk

- Toroyan, T., Peden, M.M., Iaych, K., 2015. WHO launches second global status report on road safety., Injury prevention : journal of the International Society for Child and Adolescent Injury Prevention. doi:10.1136/injuryprev-2013-040775

- Wolff, H., 2014. Value of time: Speeding behavior and gasoline prices. J. Environ. Econ. Manage. 67 1, 71-88. doi:10.1016/j.jeem.2013.11.002

\section{Acknowledgements}

Thanks are due to Experian Catalist, especially James Haigh for providing daily fuel data. We are also grateful to Colin Lansdown and Olena Plaska of Highways England for their assistance in accessing traffic data. This research did not receive any specific grant from funding agencies in the public, commercial, or not-for-profit sectors. 